Z Badań nad Książką i Księgozbiorami Historycznymi 2019. T. specjalny: Dla Niepodległej The Studies into the History of the Book and Book Collections 2019. Special issue: For an Independent Poland

Ryszard Nowicki

https://doi.org/10.33077/uw.25448730.zbkh.2020.198

Kazimierz Wielki University in Bydgoszcz

rnowicki@ukw.edu.pl

ORCID 0000-0001-8507-2086

\title{
Protection of written heritage after World War II. Józef Grycz's contribution to saving library collections
}

\begin{abstract}
The article presents the problem related to the protection of written sources in Poland after World War II. The first attempt to draw up a legal document was made in 1944. From 1945, activities, based on legal provisions, were carried on a national scale by the Ministry of Education in a planned and organized manner. The most important actions were taken in the first period of the post-war protection of library collections, i.e. until 1946. The results of the conducted research made it possible to put forward the thesis that several million books were saved during that time. Józef Grycz made a great contribution in saving valuable written heritage. The activities, conducted in extremely difficult conditions, contributed to the reconstruction of libraries, librarianship, and Polish science.
\end{abstract}

Key words: protection - library collections - law - Poland - Józef Grycz $-20^{\text {th }}$ century.

„Z Badań nad Książką i Księgozbiorami Historycznymi” - Udział zagranicznych recenzentów w ocenie publikacji; Stworzenie anglojęzycznej wersji wydawniczej publikacji; Digitalizacja tomów archiwalnych rocznika w celu zapewnienia otwartego dostępu do nich przez Internet oraz wdrożenie i utrzymanie cyfrowej platformy redakcyjnej - zadanie finansowane w ramach umowy $\mathrm{nr}$ 653/P-DUN/2019 ze środków Ministra Nauki i Szkolnictwa Wyższego przeznaczonych na działalność upowszechniającą naukę. 


\section{Before World War II}

Regaining independence by Poland in 1918 was the beginning of the development of research, public and school libraries in the free homeland. The National Library, established by the Decree of the President of the Republic of Poland on February 24, 1928 (official opening on November 28, 1930), started to accomplish significant tasks and functions. University libraries in Cracow, Warsaw, Lviv, Vilnius, and Poznań were important for the development of science. Valuable materials, being collected in family and aristocratic libraries, have been enlarging. Numerous libraries faced many problems in the interwar period, including those related to the necessary Polonisation of their collections, as a part of them was established during the Poland's partition. The development of libraries of different types, despite difficulties of that time, was rapidly interrupted in September 1939. Written heritage, related to a centuries-old history of the book and libraries in Poland, found itself in an extremely difficult situation.

It should be stated that librarians, archivists, and museum curators were not prepared to protect collections in case of war. Some people hoped that the tragedy would not happen. Józef Grycz, head of the Department of Research Libraries in the Ministry of Religious Affairs and Public Education, developed a general concept of national security measures. He made a list of 57 libraries preserving particularly valuable written materials in 1939, and a proposal of their evacuation out of the area of warfare. This postulate was not implemented, as no national legal rules concerning collections' protection were developed ${ }^{1}$. There was also no instruction on how to prepare cultural institutions in the event of war, although such document was commissioned by the congress of delegates of the Association of Polish Librarians Circles on May 8, 1939. This gap was not also fulfilled by the Council of Ministers Regulation of January 24, 1939, on duties of legal and physical entities as well as authorities and institutions in the field of air and gas defense personnel preparation in the peacetime ${ }^{2}$.

People working in cultural institutions, based on internal, ad hoc instructions, tried to protect collections themselves. Their means and possibilities were relatively limited. For instance, there was an anti-aircraft defense at the University Library in Lviv, headed by Eustachy Gaberle, the Library director. Protection of the collections of this third largest in the country university library, amounting to approximately 500000 units, was actually reduced to moving

\footnotetext{
1 A. Mężyński, Biblioteki Warszawy w latach 1939-1945, Warszawa 2010, pp. 46-47.

2 Rozporządzenie Rady Ministrów z dnia 24 stycznia 1939 r. o obowiązkach osób fizycznych i prawnych oraz władz i instytucji w dziedzinie przygotowania personelu obrony przeciwlotniczej i przeciwgazowej w czasie pokoju. Dz. U. R. P. 1939, no 10, pos. 54.
} 
the most valuable volumes to the basement, and preparation of makeshift shelters under the conditions of the ongoing war ${ }^{3}$. No more than two chests with 23 rare books from the National Library were deposited just before its outbreak, on August 5, 1939, in the Bank Gospodarstwa Krajowego, and several days later, on August 23, 49 chests with 410 parchment codices and other rare books were transported to the Sokolnicki Fort.

\section{World War II}

The outbreak of war on September 1, 1939, caused first losses in library collections, in particular in Warsaw. Alarming information concerning thefts, confiscations, milling volumes was arriving from different parts of the country, in particular, those incorporated into the Third Reich. According to the Nazi doctrine, Polish culture was to be destroyed. The two-story church of Saint Michael in Poznań was renamed as a repository of books collected by the Germans from the Greater Poland and central Poland. Approximately 2000000 volumes were gathered in this repository in September 1941, and in the following years of occupation, this stock was enlarged in general by $75 \%$. The Main Directorate of Libraries [Główny Zarząd Bibliotek] was established within the General Government, in Cracow, on July 1, 1940, managed by Gustav Abb. State libraries established in Cracow, Warsaw, Lublin, and Lviv (when the Reich occupied western Ukraine), were supervised by the former director of the University Library in Berlin. Staatsbibliothek Warshau consisted of two departments: No I (the University Library) and No II (the National Library). The Main Directorate of Libraries, as showed in the study of Andrzej Mężyński, had some merits in regard to the protection of library collections during the war ${ }^{4}$. In the eastern territories, occupied as the result of Soviet aggression of September 17, 1939, libraries did not suffer any losses. However, the process of ousting Poles from their positions, removing books contrary to communist ideology, and filling the bookshelves with propaganda literature began. The librarians were brought back to work after the Germans took over a part of Ukraine in 1941.

Origins of post-war protection of library collections are strongly related to the events of World War II. During occupation, J. Grycz started planning post-war rescue and preservation of written materials. He started secret registration of losses of Polish libraries since the beginning of this disaster ${ }^{5}$.

3 R. Nowicki, “Wojenny dziennik dyżurów OPL” Biblioteki Uniwersyteckiej we Lwowie z 1939 roku, [in:] Od armarium do kolekcji cyfrowej. Ochrona zbiorów bibliotecznych, pod red. R. Nowickiego, Bydgoszcz 2018, pp. 65-88.

4 A. Mężyński, op. cit.

5 National Library, Special Collections Unit (hereafter BN ZS), Józef Grycz - biographic materials, akc. 14917, Józef Grycz, Życiorys, Warszawa, 28 IX 1951. 
When the Ministry of Religious Affairs and Public Education was liquidated, he worked in the National Library. After its closing by the Germans, he was employed in the Municipality of the City of Warsaw. He wrote: "I took part in underground teaching and worked as a translator in the Municipality of the City of Warsaw until July 27, 1940, when - on the order of occupation authorities and with the consent of the Polish underground authorities, I took over

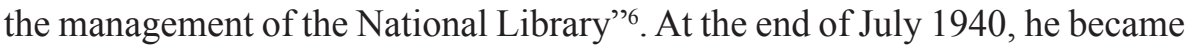
a trustee of the Department No II of the State Library (i.e. the National Library) in Warsaw, and over a year later, on October 23, 1941, he was appointed as the director of the Special Collections in the Department No II ${ }^{7}$. Fulfilling this function was in accordance with point 9 of the Instruction for the cultural workers of the underground state:

Do not cooperate with the occupant, excluding situations when such cooperation can help in saving or preserving Polish institutions or scientific, artistic or cultural collections[,]. However, prior acceptance of adequate Polish agents is always required ${ }^{8}$.

Hardly explored, but extremely important element of post-war preservation of library collection is the problem of J. Grycz's cooperation with the underground state, i.e. the Department of Education and Culture of the Government Delegation for Poland [Delegatura Rządu na Kraj], where he managed the libraries unit ${ }^{9}$. The Social Department of the Ministry of the Interior (MI) in London, referring to the reports received, prepared statements concerning the situation in the country. Materials classified as "secret" were of a source nature. Due to the possible exposure of communication with Polish territories, extreme caution was exercised, without disclosing the names. Libraries were discussed by different authors in the London reports to the MI. One of them states:

6 Ibidem.

7 A. Mężyński, op. cit., p. 128.

8 Archiwum Akt Nowych w Warszawie (Central Archives of Modern Records in Warsaw; hereafter AAN), Raport sytuacyjny okupacji niemieckiej za czas od 29 VII-30 VIII [19]40 r., Londyn, 22 XI [19]41, ch. 36 - Instrukcja dla pracowników kulturalnych.

Comment RN: I used photocopies of reports of the London Social Department of the Ministry for Internal Affairs available in AAN, with no signatures. Therefore signatures of these documents are not given hereafter.

9 The Department of Education and Culture was a part of the Government Delegate for Poland Office. It was formally established in January 1941. Its organisational structure consisted of a general secretariat (established in January 1942) and three units: of education, culture and the arts, science and higher education. Stanisław Lorentz was a head of the culture and the arts unit, followed by Józef Zaremba since 1944. It included three subunits: education of the adults, publications, and artistic culture. The latter included several professional teams, including the one for libraries, managed by J. Grycz. See: W. Grabowski, Departament Oświaty i Kultury Delegatury Rządu na Kraj, "Niepodległość i Pamięć" 2010, no 31, pp. 139-142. 
This presentation of the situation of the Polish libraries in the first year of war is based as for Warsaw - on direct identification of damages in situ, while information from other territories of the General Government ${ }^{10}$, territories annexed to the Reich and under Soviet occupation are fragmentary and not always certain, as coming from casual informers[,], often non-professionals ${ }^{11}$.

Information from Warsaw to London came, as I suppose, especially from J. Grycz, very well oriented in the situation of Warsaw libraries ${ }^{12}$

10 I.e. General Government.

11 AAN, Raport o sytuacji w Polsce, Londyn 1945 r., ch. 141.

12 In my opinion, detailed information concerning Warsaw libraries in reports of the London Ministry for Internal Affairs, Social Department, confirms very likely J. Grycz as its author, an original source. For example: "After cessation of warfare other blows began to fall on Polish libraries in Warsaw. At the beginning German administration of the Government did not take any organisational steps. However, time after time a representative of German authorities (mostly police) visited different institutions, taking over and exporting either entire book collections or parts of them. The Parliament Library was taken in total, the only one in Poland perfect collection of publications of foreign parliaments, acts, international agreements, rich sections[:] legal, economic and social. The same happened to the Judaic library of the Great Synagogue, the library of the State Archaeological Museum taken by the police headed by Dr Ernest Peterson, professor of the Rostock University. A special commission developed particularly vivid activities, joined by Dr Józef Mühlman[n] and Dr Karl Kraus. They took mostly objects of artistic values, like illuminated manuscripts, engravings, drawings, etc. Among others: a number of parchment manuscripts and a file of Aigner drawings from the National Library, approx. 10 thousands of drawings and illustrations from the Stanislaus Augustus collection from the University Library, a number of the most valuable manuscript monuments from the Zamoyski and Krasiński Library"; "The National and University Libraries, as well as recently impounded the Krasiński Library in Warsaw were joined into the one so-called State Library. Their division and relocation will disorganise them for many years, preventing their indexing and services, and exposing many works to destruction. The National Library is to contain only printed journals until 1800 . The University Library is to possess only printed foreign journals, and the Krasiński Library - only manuscripts, early printed books, cartography, geographic, music and theatrical collections. Relocations ordered by German authorities with an incomprehensible rush are in progress and effect in collections dispersion, as they are often moved to inadequate premises"; "People working for almost a year in winter in the unheated, partly ruined building of the Krasiński Library, under the leadership of a distinguished professor, were suddenly forbidden entry by the forced administrator of the state library. The most painful losses include total destruction of the Rapperswil collection (approx. 60000 volumes), even more the Military Library (approx. 250000 volumes), the technical directory in the Association of Polish Technicians' Library (approx. 30000 charts), the Zamoyski Library (approx. 70000 volumes)"; "The commission consisting of director Abb from Cracow and director Johannsen from Lviv visited libraries in Warsaw on April 2-3 [1943 comm. RN]. Unfortunate result of this visit is the regulation that some catalogues and lending forms to be kept in German"; "Private book collections of people arrested or transported to the camps are still loots of Gestapo. The whole apartment, together with a library of a former inspector of the Ministry of Religious Affairs and Education was looted in this way lately in Warsaw; he was sent in 1943 to Auschwitz"; "A number of valuable private book collections were destroyed during several weeks of fights in the Warsaw ghetto. They were either looted and destroyed, or burnt in fire raging for a long time in the ghetto. Better estimation of these losses will be extremely difficult or even impossible, due to total isolation of the ghetto, in the process of liquidation, from the rest of the city"; "More valuable collections of «the State Library» in Cracow were moved to the Wawel castle basement, for fear of air raids. There are no premises safe enough in Warsaw, therefore the most valuable collections from three libraries: the National, the University, and the Krasiński - joined by the Germans 
As agreed by the London MI, the project of the Ministry of Education and Culture (MEC) regulation concerning the protection of library collections and reconstruction of libraries was being prepared in $1944^{13}$. J. Grycz was a probable author of its content. This thesis may be controversial. At the current stage of research, there is a particular lack of documents that could explain this matter clearly. Maybe due to underground works, such a source has never arisen. I am aware of facing a difficult task. This problem has not been discussed in literature yet and needs a complete explanation. In my opinion, London took part in developing the project of regulation of 1944. This can be proved by its title - the Regulation of the Minister of Education and Culture ... concerning the protection of library collections and reconstruction of libraries, published in agreement with the Ministry of the Interior. The Department of Education and Culture acting in the country was to be transformed into the Ministry. The statement "published in agreement" mentioned above indicates previous settlements with the London MI. The day is not mentioned, as it was unknown at the time of the project's development - it was to be introduced after the planned establishment of the Ministry. Country's division into districts is not without significance, mentioned in the document, to which Grycz would refer. It should be emphasized that his concept of post-war protection of written heritage in Poland was developed

into one institution called «the State Library» by no means are protected against warfare. The whole University area, together with ruined buildings or remnants, is taken over by the army and wired. All people entering the Library have to show their id's to German guards. The Library, in the middle of the University area, is therefore actually placed in the «military» area. The State Institute of Geology building, next to the National Library, is taken over by SS men, who organised a shooting range nearby the Library, and located a machine gun on its roof, for anti-aircraft actions, despite protests of the Polish staff of the Library (subjected to a German commissioner). The most valuable collections coming from the three libraries were located (under regulation of the commissioner director of the Library) in the severely damaged building of the Krasiński Library, mostly in the basements. Nither location of this building (close to an escarpment exposed to attacks from behind the Wisła river), nor its conditions (unheated from the beginning of war and humid) do not guarantee proper security of valuable collections".

Arguments for J. Grycz as an author of information sent to London include also the following notice: "Contemporary scientific foreign publications should be collected right now in Polish centres abroad, published usually in small number of copies (in particular during the war), and impossible to complete after a short period of time. There will be huge gaps in Polish scientific libraries, due to destructions caused by warfare and vandalism of the occupants (milling all collections). In view of the great effort that even partial filling of these huge gaps and war losses would require - it would be very desirable that at least the supply of contemporary university literature in Polish academic libraries and the National Library should be considered in exile circles. - AAN, Ministerstwo Spraw Wewnętrznych. Wydział Społeczny, Sprawozdanie Nr 5/43, L.dz. K. 4670/43, Londyn, 31 VIII 1943, ch. 113: Sprawozdanie za okres od 15 II 1943 r. - 15 V 1943 r. z terenu nauki, sztuki i kultury.

13 R. Nowicki, Nieznany projekt rozporzadzenia o zabezpieczeniu zbiorów bibliotecznych i odbudowie bibliotek w powojennej Polsce, "Z Badań nad Książką i Księgozbiorami Historycznymi" 2012, vol. 6, pp. 113-126. 
during World War II. Then the plan was sketched, which would be realized and adapted to a difficult post-war reality in Poland.

The project of regulation of 1944 was developed before the Warsaw Rising. It assumed coordination of activities related to post-war protection of library collections within the whole country, in its borders from 1939. The legal act was to be published for protection and reconstruction of library collections, acquire official power upon liberation of part of the country, and remain in force until the organization of authorities of the nationwide library network. It announced the entrusting of the central management of the actions to secure and reconstruct libraries to the general director of libraries in the MEC. Temporary library districts were allotted around eight (as assumed) rescued largest libraries.

The project of library districts of 1944

\begin{tabular}{|c|c|c|}
\hline Institution & Range of activity & Remarks \\
\hline $\begin{array}{c}\text { Biblioteka Narodowa } \\
\text { (The National Library) }\end{array}$ & Warsaw & Scientific book collections \\
\hline $\begin{array}{c}\text { Biblioteka Publiczna m.st. Warszawy } \\
\text { (The Warsaw Public Library) }\end{array}$ & Warsaw & $\begin{array}{c}\text { Collections of public and } \\
\text { school libraries }\end{array}$ \\
\hline $\begin{array}{c}\text { Biblioteka Uniwersytecka w Warszawie } \\
\text { (The University of Warsaw Library) }\end{array}$ & $\begin{array}{c}\text { Warsaw and Lublin } \\
\text { voivodeships }\end{array}$ & \\
\hline $\begin{array}{c}\text { Miejska Biblioteka Publiczna w Lodzi } \\
\text { (The Lódź Municipal Library) }\end{array}$ & $\begin{array}{c}\text { Łódź voivodeship } \\
\text { Biblioteka Uniwersytecka w Wilnie } \\
\text { (The University Library in Vilnius) }\end{array}$ & $\begin{array}{c}\text { Vilnius, Nowogród, Polesie } \\
\text { and Białystok voivodeships }\end{array}$ \\
\hline $\begin{array}{c}\text { Biblioteka Uniwersytecka we Lwowie } \\
\text { (The University Library in Lviv) }\end{array}$ & $\begin{array}{c}\text { Lviv, Stanisławów, } \\
\text { Tarnopol and Wołyń } \\
\text { voivodeships }\end{array}$ & \\
\hline $\begin{array}{c}\text { Biblioteka Jagiellońska } \\
\text { (The Jagiellonian Library) }\end{array}$ & $\begin{array}{c}\text { Cracow, Kielce and Silesia } \\
\text { voivodeships }\end{array}$ & \\
\hline $\begin{array}{c}\text { Biblioteka Uniwersytecka w Poznaniu } \\
\text { (The University Library in Poznań) }\end{array}$ & $\begin{array}{c}\text { Poznań and Pomerania } \\
\text { voivodeships }\end{array}$ & \\
\hline
\end{tabular}

Source: R. Nowicki, Nieznany projekt rozporządzenia o zabezpieczeniu zbiorów bibliotecznych i odbudowie bibliotek w powojennej Polsce, "Z Badań nad Książką i Księgozbiorami Historycznymi” 2012, vol. 6, p. 123.

The draft of this regulation has never seen the daylight, and the MEC has not been established. The Department of Education and Culture was being prepared to start overt activity in the capital city liberated by the Home Army in the result of the Warsaw Rising, as it was assumed. Members of the Department 
aimed to stand against the Red Army as representatives of the legal state authorities. Due to the Warsaw Rising defeat, this idea was not realized. The Department was active in a limited scope until June $1945^{14}$. Authorities of the communist security service proceeded to work out this unit of the Delegate in 1947. The case with a codename "Działacze" (Activists) was not finished until August 12, $1956^{15}$.

Therefore the project of the first legal document aiming at the preservation of written heritage in post-war Poland was not announced ${ }^{16}$. Its text is convergent with the content of Wskazówki dla prowadzacych akcję zabezpieczenia bibliotek i zbiorów bibliotecznych [Guidelines for preserving libraries and library collections] by J. Grycz, published in $1945^{17}$, and with post-war legal documents, in particular, those concerning the determination of library districts within the country. It was possible as the result of Grycz's activity, which led to the coordination of works for the protection of library collections nationwide, and the establishment of the Chief Directorate of Libraries (Naczelna Dyrekcja Bibliotek; NDB) in the Ministry of Education on March 12, 1946.

\section{After the war}

Post-war protection of library collections was initiated in 1944 on the small part of territory free of German occupants. As time passed, it covered the whole country and lasted until December $1955^{18}$. It is divided into three periods:

- the first one, from 1944 till the end of 1946, mostly securing objects in the field,

- the second one, 1947-1949, opening at the beginning of 1947 seven magazines/sorting centres within the country, six of which formally ended their activity in 1949 ,

- the third one, 1950-1955, functioning of the Warehousing Centre for Protected Book Collections in Katowice, liquidated on December 31, $1955^{19}$.

\footnotetext{
14 W. Grabowski, op. cit., p. 146.

15 Ibidem, s. 161.

16 Presumably only few people knew about the draft regulation.

17 J. Grycz, Wskazówki dla prowadzacych akcję zabezpieczenia bibliotek i zbiorów bibliotecznych, Warszawa-Poznań 1945.

18 See: R. Nowicki, Powojenna ochrona zbiorów bibliotecznych w Polsce w latach 1944-1955. Wybór źródeł, Bydgoszcz 2013; idem, Rola katowickiej Zbiornicy Księgozbiorów Zabezpieczonych w powojennej ochronie zbiorów bibliotecznych w Polsce, Bydgoszcz 2015.

19 Actually, it was transformed into the Department of Secured Collections of the National Library in Bytom. The National Library Remote Department was liquidated on May 31, 1999, see: R. Nowicki, Oddziat Biblioteki Narodowej w Bytomiu w latach 1956-1999, [in:] Kultura ksiązki w humanistyce wspótczesnej, ed. by B. Koredczuk, K. Augustyn, Wrocław 2018, pp. 229-235.
} 
J. Grycz influenced activities focused on rescuing library collections in two periods, i.e. the first and second one. In March 1949, due to political reasons, he was removed from the work in the Ministry of Education.

Since February 1945 all library-related matters, protection included,were under the Department of Libraries in the Ministry of Education, and since March 12, 1946, the NDB, headed since April 1 by the chief director J. Grycz. As a result of his activities, the plan described in the Regulation draft of 1944 was realized, i.e. the chief director situated in one ministry supervised the socalled action of preservation and reconstruction of libraries. Moreover, as mentioned above, the Ministry of Education and Culture was not established, but two separated resorts were functioning since January 1, 1945, i.e. the Ministry of Education and the Ministry of Culture and the Arts ${ }^{20}$.

The first period was the most important for the preservation of written heritage, in which the physical survival of library materials was at stake. J. Grycz wrote: "But after the war, there will be such a lack of old and modern books, that any surviving book should be not only saved and protected but also made available for readership" ${ }^{21}$. According to estimated data losses in western and central Poland amounted to approx. $70 \%$ of total collections. Scientific and professional libraries lost approx. $45-50 \%$ of their collections during World War II, and only approx. $10 \%$ of the collections were exported from the eastern territories of the Second Polish Republic.

In the country, works were threatened with destruction, loot or deportation as so-called "trophy material" by the Red Army. Different ministers and institutions were engaged in securing libraries, often to the detriment of the collections. At first, their work was not coordinated. The contents of the Wskazówki dla prowadzacych akcję zabezpieczenia bibliotek i zbiorów bibliotecznych, directed to all the citizens, were a significant help for the rescuers of written heritage.

The values and significance of this book in practice was underlined by Władysław Pociecha in the obituary Józef Grycz. Człowiek $i$ dzieło (Józef Grycz. A man and his work) published in "Pamiętnik Biblioteki Kórnickiej"22. The author announced in Wskazówki elaboration of legal rules for the protection of the collections. He stated that saving and protection of scientific libraries and those classified as monumental can be realized based on the regulation of the President of Poland of March 6, 1928, concerning

20 When J. Grycz left the Ministry of Education, a part of competences concerning libraries was taken over by the Ministry of Culture and the Arts. The Central Management of Libraries from this resort has been responsible for the so-called security of the collections since 1951 .

21 J. Grycz, Wskazówki..., p. 12.

22 W. Pociecha, Józef Grycz. Człowiek i dzieło, "Pamiętnik Biblioteki Kórnickiej” 1955, no 5, pp. 320-331. 
the protection of monuments ${ }^{23}$. Therefore he referred to the legal heritage of the second Republic of Poland. Legal rules for post-war saving of library collections were severely lacking. The very first document in Poland where the necessity of protection of textbooks and school materials was mentioned was the request of Stanisław Skrzeszewski, director of the Education Resort, to the Polish teachers on August 1, 1944, and the next one - the Order No 120 of the Supreme Commander of the Polish Army of November 22, 1944. In that month the decree concerning the protection of abandoned collections was developed. However, the document prepared by Józef Janiczek was not adopted in Lublin. In the first post-war period, on a patch of the territory free from the German occupant, the Education Resort, by virtue of the circular of November 29, 1944, imposed an obligation to protect library collections on school inspectorates and school superintendents. Temporarily, this obligation was put on a few libraries. S. Skrzeszewski, minister of education, during his visit to Cracow on February 15, 1945, issued the regulation concerning the protection of the collections in the voivodeships freed from German occupation. The minister appointed four district library managers, who were to take over and continue the protection of library collections. These were the directors of the following libraries: The Jagiellonian Library in Cracow, the Public Library of Katowice, the Łódź Municipal Library and the University Library in Poznań. In a shortened form the document referred to the draft regulation of 1944. Considering mass destruction in the capital, no district was identified subject to Warsaw libraries. District library managers met numerous difficulties, including those related to lack of country administration division. In mid-February 1945 fights with the Germans continued. Due to that reason, the district manager for Poznań and Pomerania voivodeships Aleksander Birkenmajer was unable to start the protection of library collections ${ }^{24}$. The regulation of February 15, 1945, was of pure temporary nature.

Soon after the Germans were driven out from Warsaw by the Red Army, J. Grycz managed works of the National Library until March 31, 1945. On April 1 of this year he started his work in the Department of Libraries, Ministry of Education ${ }^{25}$. He energetically initiated realization of the plans concerning the establishment of the first in the history of Polish librarianship body coordinating works of all libraries, i.e. NDB, and protection of library collections according to the program described in Wskazówki dla prowadzacych akcje zabezpieczenia bibliotek i zbiorów bibliotecznych. He stated:

23 Rozporządzenie Prezydenta Rzeczypospolitej z dnia 6 marca 1928 r. o opiece nad zabytkami, Dz. U. R. P. 1928, no 29, pos. 265.

24 Pre-war director of the University Library in Poznań reached the city on March 18, 1945.

25 BN ZS, Józef Grycz - materiały biograficzne, akc. 14917: A.[lodia] G.[ryczowa], Życiorys Józefa Grycza, [Warszawa], 10 stycznia [19]59. 
When war and occupation have desolated our libraries, devastated the Polish book, the first and indispensable task was the protection of rescued collections. Those in the libraries required, almost everywhere, ordering, checking everything, filling in the gaps, repairing rooms and internal devices. Unfortunately, there were only a few such libraries. Most of the collections were destroyed, exported to Germany or dispersed ${ }^{26}$.

Grycz developed contents of new documents, including regulations of the Ministry of Education on July 9, 1945, concerning taking over book collections from plenipotentiaries for land reform, and on August 4, 1945, concerning protection and usage of so-called abandoned and deserted book collections. In autumn 1945 he took part in the first post-war conference of district library inspectors in Pabianice. As a representative of the Ministry of Education, he approved then the idea presented by Stanisław Sierotwiński, director of the Chief Directorate of Libraries for Cracow, Kielce and Rzeszów voivodeships, concerning the appointment of a special delegate in Cracow. The Ministry of Education Delegation for protection of abandoned and deserted book collections was established on December 1, 1945, pursuant to art. 1 of the Act on June 4, 1920, on a temporary education system. Therefore, once again an attempt was made to refer to the legal regulation of the Second Republic of Poland. One has to admit, that there were no references to activities related to library protection in this legal document, and the Ministry for Religious Affairs and Public Education did not resume its activity after the war $^{27}$.

The Cracow Delegation was managed by S. Sierotwiński, supervising the country's territory divided into six districts: I Cracow, II Wrocław, III Szczecin, IV Gdańsk, V Olsztyn, and VI Lublin. J. Grycz was his direct supervisor. During 13 months of the Delegation's activity, i.e. until the end of 1946, Sierotwiński protected approx. 5,5 million volumes in more than 170 locations all over Poland, mostly of German provenance. The books were divided by the Ministry of Education. When the Cracow Delegation closed, J. Grycz, with great commitment began to create warehousing / sorting centres, initiating in this way the second period of the post-war protection of library collections. He discussed with the colleagues from the field in the Ministry to settle their number and location. The warehousing centres were established on February 1, 1947, in Gdańsk, Katowice, Cracow, Poznań, Szczecin, Toruń, and Wrocław. Basic duties of their employees included (among others): searching for and collection of library materials, their storage, segregation according to the Ministry

26 BN ZS, Józef Grycz - materiały do działalności publicznej, akc. 14927, vol. 3: J. Grycz, Bibliotek, [Warszawa], $1946 \mathrm{r}$.

27 "Chief management and supervision of public education in the People's Republic of Poland belong to the Minister of Religious Affairs and Public Education. Higher Education is managed directly by the Minister of Religious Affairs and Public Education" - art. 1 of Ustawa z dnia 4 czerwca 1920, o tymczasowym ustroju władz szkolnych, Dz. U. 1920, no 50, pos. 304. 
of Education instruction of January 25, 1946, concerning works with protected book collections. The instruction was written by J. Grycz, who rightly thought that these works should be finished as soon as possible. He scheduled the deadline for these activities on August 31, 1946. However, this deadline was postponed several times, due to a huge amount of books being protected, including those from so-called Recovered Territories. Moreover, numerous difficulties, related (among others) to limited funds, prevented the realisation of the plan in due time ${ }^{28}$.

The chief director of libraries developed also the contents of the first Act on the libraries and protection of library collections, on April 17, 1946, fundamental for post-war activities focused on the protection of written materials. The document was being developed just during the war, in conspiracy ${ }^{29}$.

J. Grycz played a key role in the post-war protection of library collections in Poland ${ }^{30}$. He did not work alone. It should be emphasized that most of the rescuers working together with the chief director of libraries were educated in the inter-war period (among others: A. Birkenmajer, S. Sierotwiński, Marian Pelczar, Stefan Burchardt, Antoni Knot). All of them gained experience in practice. They had no models or experiences in such activities on such a huge scale. Warsaw was a decisive center, due to J. Grycz.

\section{Conclusions}

The problem discussed in this article does not complete the topic. Difficulties come from lack of publications and studies concerning post-war protection of written heritage. The hitherto studies focus on evaluating losses of World War II. The literature on this topic is rich and constantly expanded with valuable publications. However, there are many issues to be clarified, including those related to the circumstances of developing by J. Grycz the draft regulation of 1944, in conspiracy conditions. Perhaps this problem will stay unsolved, source materials have been irrevocably lost or they have never existed. Cooperation with the London government and the underground state was threatened with severe penalties. Works were realized in top secret.

The protection of written materials has started just before World War II, without national regulations in case of an exceptional event. J. Grycz was aware of the threat and the necessity of post-war activities being realized

28 BN ZS, Józef Grycz - materiały do działalności publicznej, akc. 14927, vol. 3: J. Grycz, Budżet Bibliotek na R. 1947, [Warszawa], 27 I 1947 r.

29 BN ZS, Józef Grycz - materiały biograficzne, akc. 14917: A.[lodia] G.[ryczowa], Życiorys Józefa Grycza, [Warszawa], 10 I [19]59 r.

30 R. Nowicki, Rola Józefa Grycza w powojennej ochronie zbiorów bibliotecznych, "Z Badań nad Książką i Księgozbiorami Historycznymi” 2011, vol. 5, pp. 89-108. 
in an organised and centralized way. The first draft of legal regulation adapted to the circumstances of the Second Republic of Poland was developed in the country, in cooperation with the London government. It was exceptional, as a similar document had never existed before. The concept presented influenced significantly the contents of following legal documents and methods of work in the field. The original plan, in the face of the Warsaw Rising defeat and changes of post-war Poland borders, had no chances of realization. Therefore development of legal regulations was necessary, adapted to the new reality, with Poland in the area of the Soviet Union influence.

Activities realised with huge determination by a few books rescuers, according to j. Grycz's guidelines, brought measurable effects, in particular in the first period, i.e. the years 1944-1946. Several millions of volumes were saved at that time. At least 10 million volumes were protected in total in the years 1944-1955, most of them intended for reconstruction of libraries and librarianship in Poland.

The first period of post-war protection of library collections as of exceptional importance for saving collections, including materials from post-courtyard libraries, intentionally deprived of due care by representatives of the new authorities. They were particularly vulnerable to robbing, looting, physical destruction. Rescuing precious written heritage for future generations was possible in the result of planned and effective actions undertaken by J. Grycz.

Translated by Matgorzata Kisilowska

Il. 1. Fragment of the manuscript of "Rota" [The Oath] by Maria Konopnicka. Source: Voivodeship and Municipal Public Library in Bydgoszcz, manuscript 350/ III, photo by Ryszard Nowicki

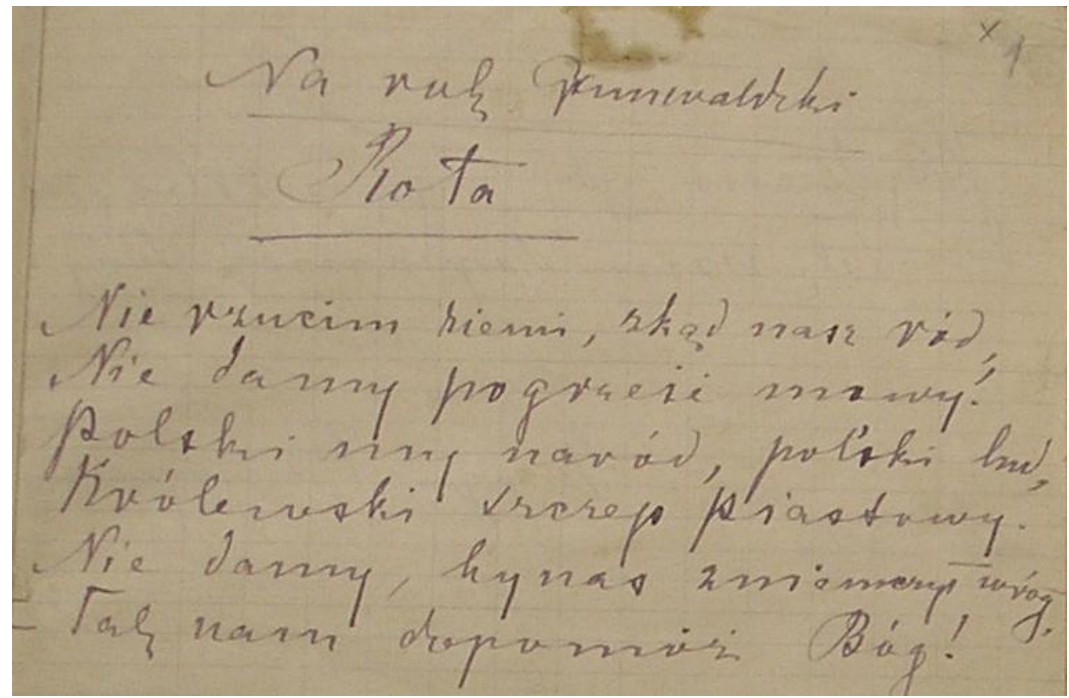


Il. 2. Fragment of the score of "Rota" [The Oath] by Feliks Nowowiejski. Source: Voivodeship and Municipal Public Library in Bydgoszcz, manuscript 350/III, photo by Ryszard Nowicki

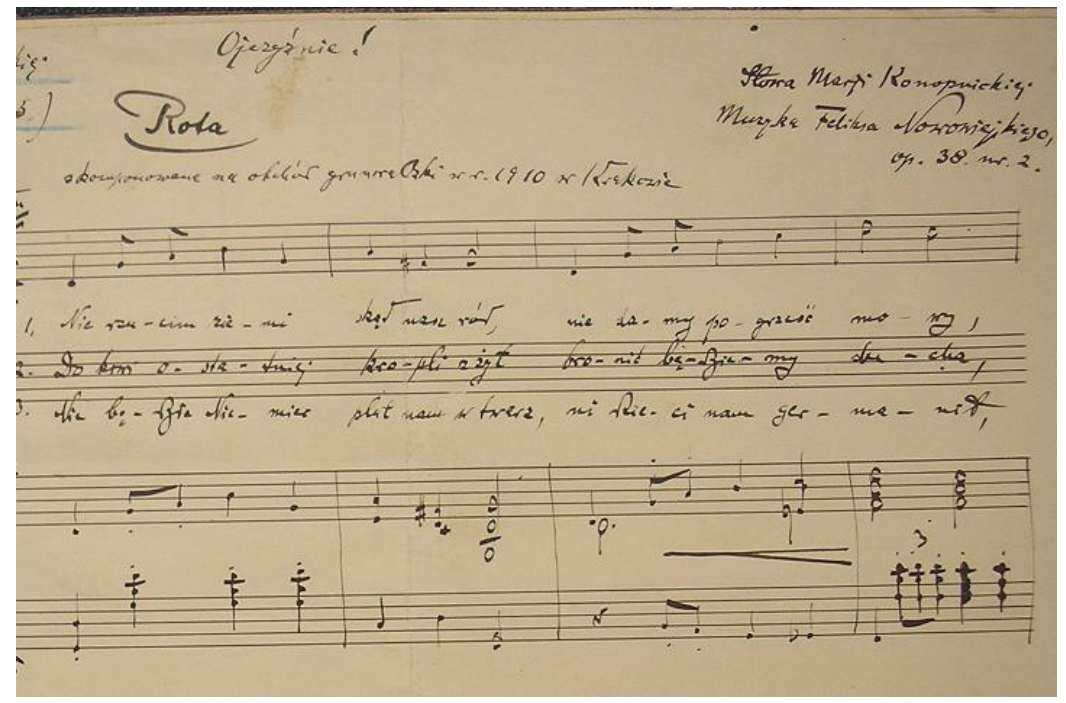

Il. 3. Ephemera of the bookstore of Instytut Wydawniczy "Biblioteka Polska" ("Polish Library" Publishing Institute). Source: Voivodeship and Municipal Public Library in Bydgoszcz, Special Collections Ephemera XVI.2 - Biblioteka Polska, photo by Ryszard Nowicki

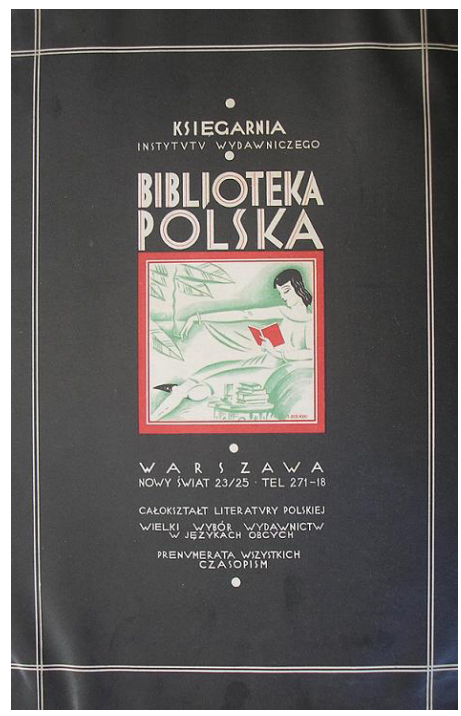


I1. 4. Draft of a calendar for 1940 of the bookstore of Instytut Wydawniczy Biblioteka Polska. Source: Voivodeship and Municipal Public Library in Bydgoszcz, Special Collections Ephemera XVI.2 - Biblioteka Polska, photo by Ryszard Nowicki

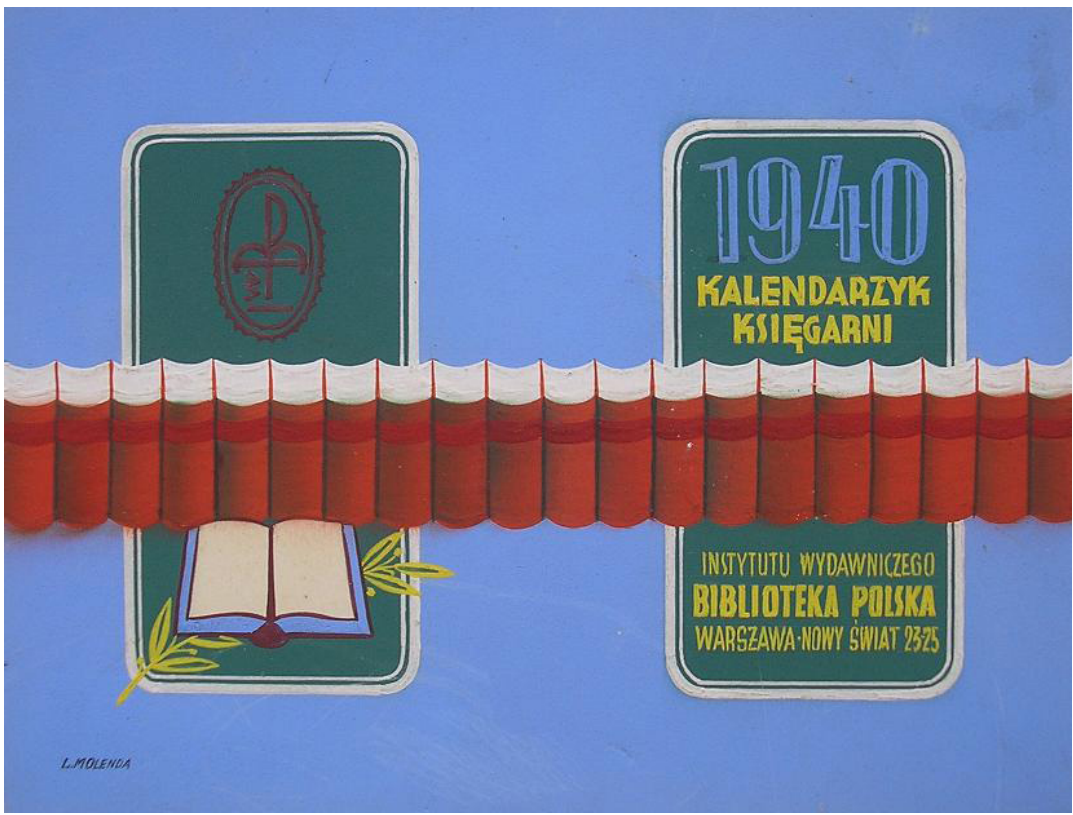

\section{Literature (selection)}

Source materials

- Manuscripts

Archiwum Akt Nowych w Warszawie (Central Archives of Modern Records in Warsaw), Raport sytuacyjny okupacji niemieckiej za czas od 29 VII-30 VIII [19]40 r., Londyn, 22 XI [19]41, ch. 36 - Instrukcja dla pracowników kulturalnych.

Archiwum Akt Nowych w Warszawie (Central Archives of Modern Records in Warsaw), Raport o sytuacji w Polsce, Londyn 1945 r., ch. 141.

Archiwum Akt Nowych w Warszawie (Central Archives of Modern Records in Warsaw), Ministerstwo Spraw Wewnętrznych. Wydział Społeczny, Sprawozdanie Nr 5/43, L.dz. K. 4670/43, Londyn, 31 VIII 1943, ch. 113: Sprawozdanie za okres od 15 II 1943 r. 15 V 1943 r. z terenu nauki, sztuki i kultury.

Biblioteka Narodowa, Zbiory Specjalne (National Library, Special Collections Unit), Józef Grycz - materiały biograficzne, akc. 14917, Józef Grycz, Życiorys, Warszawa, 28 IX 1951.

Biblioteka Narodowa, Zbiory Specjalne (National Library, Special Collections Unit), Józef Grycz - materiały biograficzne, akc. 14917, A.[lodia] G.[ryczowa], Życiorys Józefa Grycza, [Warszawa], 10 stycznia [19]59. 
Biblioteka Narodowa, Zbiory Specjalne (National Library, Special Collections Unit), Józef Grycz - materiały do działalności publicznej, akc. 14927, vol. 3: J. Grycz, Biblioteki, [Warszawa], $1946 \mathrm{r}$.

Biblioteka Narodowa, Zbiory Specjalne (National Library, Special Collections Unit), Józef Grycz - materiały do działalności publicznej, akc. 14927, vol. 3: J. Grycz, Budżet Bibliotek na R. 1947, [Warszawa], 27 I 1947 r.

- Printed materials

Grycz J., Wskazówki dla prowadzących akcję zabezpieczenia bibliotek i zbiorów bibliotecznych, Warszawa-Poznań 1945.

Legal documents

Rozporządzenie Prezydenta Rzeczypospolitej z dnia 6 marca 1928 r. o opiece nad zabytkami, Dz. U. R. P. 1928, no 29, pos. 265.

Rozporządzenie Rady Ministrów z dnia 24 stycznia 1939 r. o obowiązkach osób fizycznych i prawnych oraz władz i instytucji w dziedzinie przygotowania personelu obrony przeciwlotniczej i przeciwgazowej w czasie pokoju. Dz. U. 1939, no 10, pos. 54.

Ustawa z dnia 4 czerwca 1920 r. o tymczasowym ustroju władz szkolnych, Dz. U. 1920, no 50 , pos. 304 .

Literature

Grabowski W., Departament Oświaty i Kultury Delegatury Rządu na Kraj, "Niepodległość i Pamięć” 2010, no 31, pp. 139-162.

Mężyński A., Biblioteki Warszawy w latach 1939-1945, Warszawa 2010.

Nowicki R., “Wojenny dziennik dyżurów OPL” Biblioteki Uniwersyteckiej we Lwowie z 1939 roku, [in:] Od armarium do kolekcji cyfrowej. Ochrona zbiorów bibliotecznych, pod red. R. Nowickiego, Bydgoszcz 2018, pp. 65-88.

Nowicki R., Nieznany projekt rozporządzenia o zabezpieczeniu zbiorów bibliotecznych i odbudowie bibliotek w powojennej Polsce, "Z Badań nad Książką i Księgozbiorami Historycznymi” 2012, vol. 6, pp. 113-126.

Nowicki R., Oddział Biblioteki Narodowej w Bytomiu w latach 1956-1999, [in:] Kultura książki w humanistyce współczesnej, ed. by B. Koredczuk, K. Augustyn, Wrocław 2018, pp. 229-235.

Nowicki R., Powojenna ochrona zbiorów bibliotecznych w Polsce w latach 1944-1955. Wybór źródel, Bydgoszcz 2013.

Nowicki R., Rola Józefa Grycza w powojennej ochronie zbiorów bibliotecznych, “Z Badań nad Książką i Księgozbiorami Historycznymi” 2011, vol. 5, pp. 89-108.

Nowicki R., Rola katowickiej Zbiornicy Księgozbiorów Zabezpieczonych w powojennej ochronie zbiorów bibliotecznych w Polsce, Bydgoszcz 2015.

Pociecha W., Józef Grycz. Człowiek i dzieło, "Pamiętnik Biblioteki Kórnickiej” 1955, no 5, pp. 320-331. 